\title{
Strategic Planning Process to Company Performance
}

\author{
Sisay Te'ame Desta, $M B A$ \\ Jigjiga University, Jigjiga, Ethiopia
}

Doi:10.19044/esj.2019.v15n22p165 URL:http://dx.doi.org/10.19044/esj.2019.v15n22p165

\begin{abstract}
Strategic planning process is important for strategic management of companies. Organizations from both private and public sector are increasingly embracing the practice of strategic planning process in anticipation that this will translate to improved performance. Past studies have mainly focused on the direct relationship between strategic planning and performance and did not give attention to the specific steps that make up the strategic planning process. The manner and extent to which each of the steps is practiced could have implications on the expected strategic planning results. This study set out to examine strategic planning process to firm performance giving attention to the strategic planning steps. Furthermore, it contributes to understand the nature and practice of strategic planning process in Ethiopian companies. To achieve this objective, descriptive type of research was employed in Dire Dawa National Cement. Descriptive type of research design helps to depict accurately the characteristics of a particular individual, situation and group.
\end{abstract}

Keywords: Strategic Planning, Strategic Planning Process, Firm Performance

\section{Introduction}

\section{Background of the Study}

Strategic planning is an organization's process of defining its strategy, or direction, and making decisions on allocating its resources to pursue this strategy. In order to determine the direction of the organization, it is necessary to understand its current position and the possible avenues through which it can pursue a particular course of action.

Strategic planning is an effective way of improving company performance. This, at least, has been the general perception in the strategic management literature to date. Over time the concept and practice of strategic planning has been embraced worldwide and across sectors because of its perceived contribution to organizational effectiveness. Today organizations from both the private and public sectors have taken the practice of strategic planning seriously as a tool that can be utilized to fast track their performances. Strategic planning is arguably important ingredient in the conduct of strategic 
management. Steiner (1979) noted that the framework for formulating and implementing strategies is the formal strategic planning system. Porter (1985) noted that despite the criticism leveled against strategic planning during the 1970s and 80s, it was still useful and it only needed to be improved and recited. Greenley (1986) noted that strategic planning has potential advantages and intrinsic values that eventually translate into improved firm performance. It is, therefore, a vehicle that facilitates improved firm performance.

Strategic planning is a very important business activity. It is practiced widely informally and formally. Strategic planning and decision processes should end with objectives and a roadmap of ways to achieve them. The goal of strategic planning mechanisms like formal planning is to increase specificity in business operation, especially when long-term and high-stake activities are involved. Many of the studies on the relationship between strategic planning and firm performance were done between 1970s and early 1990s, in the developed economies. These studies focused on the direct relationship between strategic planning and firm performance. Although the studies within the African context by Woodburn (1984), Adegbite (1986) and Fubara (1986) noted that firms that practiced strategic planning recorded better performance compared to non-planners, their focus, however, was on the formality of planning rather than the link between planning and firm performance. It is noted that the past studies did not give attention to the individual steps that make up the strategic planning process. It is perceived that the manner and extent to which each of the strategic planning steps is addressed could have implications on the realization of the expected corporate goals. This study set out to examine the contribution of strategic planning to firm performance in a developing country's context particularly National Cement Share Company, Dire Dawa, Ethiopia.

\subsection{Statement of the Problem}

The environments in which public, private and non-profit organizations operate have become not only increasingly uncertain in recent years but also more tightly interconnected; thus changes anywhere in the system reverberate unpredictably - and often chaotically and dangerouslythroughout the society. This increased uncertainty and interconnectedness requires a fourfold response from public, private and non-profit organizations (and from communities). This shows that strategic planning is one of the tools that can be used as an instrument to respond to the unpredictable competitive environment. According to John (2004), Strategic planning can help leaders and managers of public and non-profit organizations think, learn, and act strategically.

Many of the studies on the relationship between strategic plan and organization performance were done between 1970s and early 1990s. These 
studies focused on the direct relationship between strategic planning and organization performance. Although the studies within the African context by Woodburn (1984), Adegbite (1986) and Fubara (1986) noted that firms that practiced strategic planning recorded better performance compared to nonplanners, their focus, however, was on the formality of planning rather than the link between planning and organization performance Previous studies of manufacturing firms (Ansoff et al., 2001; Herold, 2001; Karger and Malik, 2000; Thune and House, 1999) have indicated that strategic planning results in superior financial performance, measured in terms of generally accepted financial measures (e.g., sales, net income, ROI, ROE, ROS). Subsequent studies (Armstrong, 1999; Greenley, 1986; Mintzberg, 1994; Shrader et al., 1984; Akinyele, 2007) have contradicted the notion of a strategic planning superior performance relationship. However, studies (Miller and Cardinal, 1994; Schwenk and Shrader, 1993) provide convincing evidence that strategic planning does indeed result in superior financial performance. One stream of strategic planning research has raised the issue of whether the length of time a firm or organization has been involved in the strategic planning process has any impact on performance. In their study of the private sector (Gup and Whitehead, 2000; Burt, 1998; Kudla, 1980; Lebans and Euske, 2006; Leontiades and Tezel, 2006) tested the notion that strategic planning only pays off after a period of time. They found no statistically significant relationship between the lengths of time organizations had been engaged in the strategic planning process and their organizational performance.

The fact that organization managers are becoming more intensively engaged in these activities implies that they acknowledge (either consciously or unconsciously) a relationship between strategic planning intensity and improved organizational performance (Hunger, 1990; Johnson, 2002; Kallman and Shapiro, 1998; Paley, 2004; Porter, 1989). Indeed, a previous study tested this relationship and found that organizations that planned with greater intensity, regardless of whether their strategic planning process was formal or informal, outperformed those organizations that planned with less intensity (Hopkins and Hopkins, 1994).

In support of this position researches (Miller and Cardinal, 1994; Chandler, 1998; Davis, 2004; Denning, 1997; Haveman, 1993; Hax and Majluf, 1991; Hayes, 2003; Hitt et al., 1990; Hunsaker, 2001) set forth and tested the notion, with affirmative results, that the amount of strategic planning a firm or an organization conducts positively affects its financial performance.

Given the fact that even strategic planning is embraced in the developing countries like Ethiopia, most organizations know that strategic planning is most important tool for the profitability of the organization, but few of them have a deep and comprehensive knowledge and apply it as well 
in the organization. This study was undertaken to determine if there is a contribution of strategic plan to organization performance.

The concept for this study was based upon the management premise that planning, specifically strategic planning is an important part of the management function. The strategic planning process can assist in this environment as it involves taking information from the environment and deciding on organizational mission, objectives, strategies, portfolio plan and activities to achieve these plans. The purpose was to set a broad base of knowledge for the organization particularly the National Cement Share Company, Dire Dawa, on strategic planning and to review its contribution on the performance of Dire Dawa National Cement.

According to the researcher, there is an absence of study on strategic planning and its contribution to organizational performance, which at the long run enhances organizational survival and benefits firms having a formal strategic planning process outperform those that do not. Furthermore, firms taking a proactive strategic approach have better performance than those taking a reactive strategic approach. This evidence demonstrates the usefulness and, in fact necessity of having a formal, proactive strategic planning in an organization, whether it be large or small, and the researcher feels it is worth doing the study in the area in National Cement Share Company, Dire Dawa, Ethiopia.

\subsection{Research Questions}

The researcher endeavored to find answer to the issue which is related to the following question:

$\checkmark$ What is the contribution of strategic planning to organizational performance: the case of National Cement Share Company, Dire Dawa, Ethiopia?

\subsection{Objectives of the Study}

The specific objective of the study was to assess the contribution of strategic planning to organizational performance: the case of National Cement Share Company, Dire Dawa, Ethiopia.

\subsection{Limitations of the Study}

The researcher used excel to get the frequency and percentile of the respondents because of lack of comprehensive knowhow to use latest and more structured software like SPSS within the time given. Furthermore, all factors influencing organizational performance (like financial performance, growth, customer, and employee satisfaction) were not considered in this study due to time, budget and other resource constraint. 


\section{Literature Review}

\subsection{The Idea of Strategic Planning}

Strategic planning has been explained by various writers and scholars in different but complementary ways. Drucker (1954) contends that strategic planning is management by plans, an analytical process and is focused in making optimal strategic decisions. Other writers have expanded on Drucker's definition. Ansoff (1970) conceptualizes strategic planning as the process of seeking a better match between a firm's products or technology and its increasingly turbulent markets. He looks at it in terms of change from a familiar environment to an unfamiliar world of strange technologies, strange competitors, new consumer attitudes, new dimensions of social control and above all, a questioning of the firm's role in society. Sharing this view, Hofer and Schendel (1978) define strategic planning as an evolution of managerial response to environmental change in a focus moving from internal structure and production efficiency, to the integration of strategy and structure and production innovation, multinational expansion and diversification. Wendy (1997) explained strategic planning as the process of developing and maintaining consistency between the organization's objectives and resources and its changing opportunities. Wendy (1997) further argues that strategic planning aims at defining and document an approach to doing business that will leads to satisfactory profits and growth.

Steiner (1979) defines strategic planning as the systematic and more or less formalized effort of a company to establish basic company purposes, objectives, policies and strategies. It involves the development of detailed plans to implement policies and strategies to achieve objectives and basic company purposes. On the same breath, Bateman and Zeithml (1993) view planning as a conscious, systematic process during which decisions are made about the goals and activities that an individual, group, work unit or organization will pursue in the future. It provides individuals and work units a map to follow in their future activities. Hax and Majluf (1991) supporting this argument explain strategic planning as a disciplined and well-defined organizational effort aimed at the complete specification of a firm's strategy and the assignment of responsibilities for execution. From these diverse views expressed above, strategic planning in its general and basic understanding can be said to be a process of selecting organizational goals and strategies, determining the necessary programs to achieve specific objectives enroute to the goals, and establishing the methods necessary to ensure that the policies and programs are implemented.

Wendy (1997) explains that strategic planning process comprises of three main elements which helps turn an organizations vision or mission into concrete achievable. These are the strategic analysis, strategic choice and strategic implementation. The strategic analysis encompasses setting the 
organization's direction in terms of vision, mission and goals. Therefore, this entails articulating the company's strategic intent and directing efforts towards understanding the business environment. Strategic choice stage involves generating, evaluating and selecting the most appropriate strategy. Strategy implementation stage consists of putting in place the relevant policies and formulating frameworks that will aid in translating chosen strategies into actionable forms. For purposes of this study, the three main steps have been sequenced into five generic components that can be considered to complete the strategic planning process. These are; defining firm's corporate direction, appraisal of business environment, identification and analysis of firm's strategic issues, strategy choice and development of implementation, evaluation \& control systems.

\subsection{The Strategic Planning Process}

In today's highly competitive business environment, budget-oriented planning or forecast-based planning methods are insufficient for a large corporation to survive and prosper. The firm must engage in strategic planning that clearly defines objectives and assesses both the internal and external situation to formulate strategy, implement the strategy, evaluate the progress, and make adjustments as necessary to stay on track. According to Manoj Kumar (2013) strategic planning involves the following elements: A simplified view of the strategic planning process is shown by the following diagram:

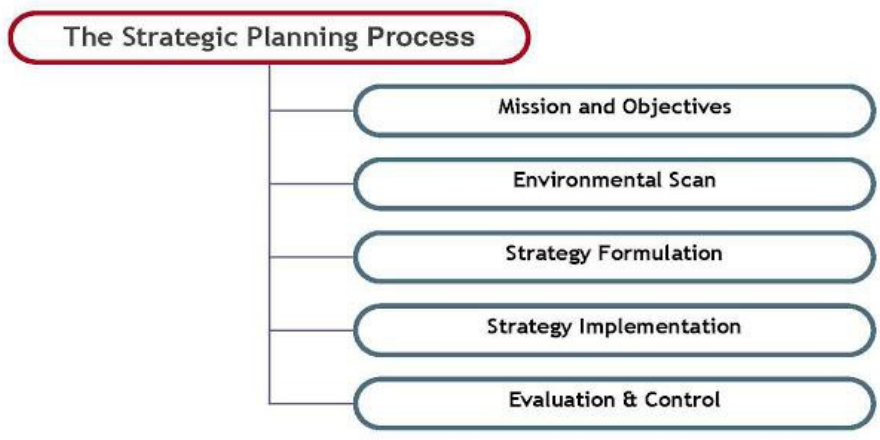

\section{Mission and Objectives:}

The mission statement describes the company's business vision, including the unchanging values and purpose of the firm and forward-looking visionary goals that guide the pursuit of future opportunities. Guided by the business vision, the firm's leaders can define measurable financial and strategic objectives. Financial objectives involve measures such as sales targets and earnings growth. Strategic objectives are related to the firm's 
business position, and may include measures such as market share and reputation.

\section{Environmental Scan:}

The environmental scan includes the following components:

$\checkmark$ Internal analysis of the firm

$\checkmark$ Analysis of the firm's industry(task environment)

$\checkmark$ External macro-environment (PEST analysis)

The internal analysis can identify the firm's strengths and weaknesses and the external analysis reveals opportunities and threats. A profile of the strengths, weaknesses, opportunities, and threats is generated by means of a SWOT analysis. An industry analysis can be performed using a framework developed by Michael Porter known as Porter's five forces. This framework evaluates entry barriers, suppliers, customers, substitute products, and industry rivalry.

\section{Strategy Formulation:}

Given the information from the environmental scan, the firm should match its strengths to the opportunities that it has identified, while addressing its weaknesses and external threats. To attain superior profitability, the firm seeks to develop a competitive advantage over its rivals. A competitive advantage can be based on cost or differentiation. Michael Porter identified three industry-independent generic strategies from which the firm can choose.

\section{Strategy Implementation:}

The selected strategy is implemented by means of programs, budgets, and procedures. Implementation involves organization of the firm's resources and motivation of the staff to achieve objectives. The way in which the strategy is implemented can have a significant impact on whether it will be successful. In a large company, those who implement the strategy likely will be different people from those who formulated it. For this reason, care must be taken to communicate the strategy and the reasoning behind it. Otherwise, the implementation might not succeed if the strategy is misunderstood or if lower-level managers resist its implementation because they do not understand why the particular strategy was selected.

\section{Evaluation \& Control}

The implementation of the strategy must be monitored and adjustments made as needed.

Evaluation and control consists of the following steps:

- Define parameters to be measured 
- Define target values for those parameters

- Perform measurements

- Compare measured results to the pre-defined standard

- Make necessary changes

\subsection{Organizational Performance}

Organizational performance is described as an organization's ability to acquire and utilize its scarce resources and valuables as expeditiously as possible in the pursuit of its operations goals (Griffins, 2006). Organizations have an important role in our daily lives and therefore, successful organizations represent a key ingredient for developing nations. Thus, many economists consider organizations and institutions similar to an engine in determining the economic, social and political progress. Precisely for this reason, in the last 22 years, there were 6 Nobel prizes awarded to researchers who have focused on the analysis of organizations and institutions. Continuous performance is the focus of any organization because only through performance organizations are able to grow and progress.

Thus, organizational performance is one of the most important variables in the management research and arguably the most important indicator of the organizational performance.

Although the concept of organizational performance is very common in the academic literature, its definition is difficult because of its many meanings. For this reason, there isn't a universally accepted definition of this concept.

In the '50s organizational performance was defined as the extent to which organizations, viewed as a social system fulfilled their objectives (Georgopoulos \& Tannenbaum, 1957: p. 535). Performance evaluation during this time was focused on work, people and organizational structure.

Later in the $60 \mathrm{~s}$ and $70 \mathrm{~s}$, organizations have begun to explore new ways to evaluate their performance so performance was defined as an organization's ability to exploit its environment for accessing and using the limited resources (Yuchtman \& Seashore, 1967: p. 379).

The years $80 \mathrm{~s}$ and $90 \mathrm{~s}$ were marked by the realization that the identification of organizational objectives is more complex than initially considered. Managers began to understand that an organization is successful if it accomplishes its goals (effectiveness) using a minimum of resources (efficiency). Thus, organizational theories that followed supported the idea of an organization that achieves its performance objectives based on the constraints imposed by the limited resources (Lusthaus \& Adrien, 1998). In this context, profit became one of the many indicators of performance.

The authors Lebans \& Euske (2006: p. 71) provide a set of definitions to illustrate the concept of organizational performance: 
$>$ Performance is a set of financial and nonfinancial indicators which offer information on the degree of achievement of objectives and results (Lebans \& Euske 2006 after Kaplan \& Norton, 1992).

$>$ Performance is dynamic, requiring judgment and interpretation.

$>$ Performance may be illustrated by using a causal model that describes how current actions may affect future results.

$>$ Performance may be understood differently depending on the person involved in the assessment of the organizational performance (e.g. performance can be understood differently from a person within the organization compared to one from outside).

$>$ To define the concept of performance is necessary to know its elements characteristic to each area of responsibility.

$>$ To report an organization's performance level, it is necessary to be able to quantify the results.

$>$ Performance is a set of financial and nonfinancial indicators which offer information on the degree of achievement of objectives and results (Lebans \& Euske 2006 after Kaplan \& Norton, 1992).

$>$ Performance is dynamic, requiring judgment and interpretation.

$>$ Performance may be illustrated by using a causal model that describes how current actions may affect future results.

$>$ Performance may be understood differently depending on the person involved in the assessment of the organizational performance (e.g. performance can be understood differently from a person within the organization compared to one from outside).

$>$ To define the concept of performance is necessary to know its elements characteristic to each area of responsibility.

To report an organization's performance level, it is necessary to be able to quantify the results.

\subsection{Link Between Strategic Planning and Company Performance}

It is conceptualized that firms that have effectively embraced strategic planning, records better performance as compared to those that have not. Hofer and Schendel (1978), Henderson (1979), Greenley (1986), Miller and Cardinal (1994) and David (1997) argue that firms record improved performance once they effectively embrace strategic planning. Carrying out the various steps in the strategic planning process is expected to facilitate the realization of organizational effectiveness. By defining a company's purpose and goals, strategic planning provides direction to the organization and enhances coordination and control of organization activities. McCarthy and Minichiello (1996), note that a company's strategy provides a central purpose and direction to the activities of the organization and to the people who work in it. Howe 
(1986) and Kotter (1996) argue that the primary goal of strategic planning is to guide the organization in setting out its strategic intent and priorities and refocus itself towards realizing the same. Porter (1980), Greenley (1986), Miller and Cardinal (1994), Hax and Majluf (1991) and Grant (1998) argue that an objective analysis of external and internal environment facilitates the establishment of the firm-environment fit and improved decision-making. Adding to this view, Porter (1980), Quinn (1980), Ohmae (1983) and Kotter (1996) note that the identification of strategic issues and, strategy analysis and selection facilitates the achievement of efficient allocation of resources, sustainable competitive advantage, and improved innovation. It is also perceived that the development of implementation programme, evaluation and control systems facilitates smooth execution and implementation of the planned tasks.

\subsection{Empirical Basis: Strategic Planning and Organization Performance \\ Various empirical studies have been done to establish the relationship} between strategic planning and firm performance with varied conclusions. The initial studies include that done by Thune and House (1970). Thune and House studied 36 companies employing the approach of examining the performance of each company both before and after formal strategic planning was initiated.

This covered both informal and informal planners. The comparison showed that formal planners outperformed the informal planners on all the performance measures that were used. Herold (1972) in an attempt to crossvalidate Thune and House (1970) study, surveyed 10 companies, comparing performance of formal and informal planners over a 7-year period. Based on the survey results, He concluded that formal planners outperform informal planners and hence, supporting the results of Thune and House (1970).

Gershefski (1970) in his survey compared the growth of sales in companies over a 5-year period before strategic planning was introduced, and over a period of 5 years after planning was introduced. The results of the comparison led Gershefski to conclude that companies with formal strategic planning outperformed companies with little planning. Ansoff (1970) studied 93 firms using various variables of financial performance. The findings revealed that companies, which do extensive strategic planning, outperformed the other companies. Karger and Malik (2000), taking a similar approach to that taken by Ansoff, compared the values of a range of variables of planners to those of the non-planners and based on the results concluded that the planners outperformed the non-planners.

However, other studies attempting to establish the relationship between strategic planning and firm performance have not been conclusive in their findings. They have not claimed the existence of a relationship between 
strategic planning and performance. They conclude that higher levels of performance does not necessarily relate to the utilization of strategic planning. These include Fulmer and Rue (1974), Grinyer and Norburn (1975), Kudla (1996), and Leontiades and Tezel (2006).

Howe (1986) argues that although the evidence is far from being robust there are grounds for suggesting, on the basis of research, that there is a link between strategic planning and profit performance in business. Howe points out that there is a positive statistical relationship between company financial performance and the detail of objective setting and the fixing of responsibility for long-term decisions. Companies that failed did so not because of the inherent disadvantage in terms of size or financial resources, but because of poor strategic decision-making. Caeldries and Van Dierdonck (1988) surveyed 82 Belgian Business firms and reported a link between strategy and performance. They noted that strategy enables a firm to strengthen its competitive position, and facilitates integration and coordination of members' behavior. Pealtie (1993) observed that the main reason for the introduction of formalized strategic planning is to improve company performance through the development and implementation of better strategies. Strategy documentation as a process forms the watershed between strategy formulation and implementation. Pealtie noted that managing a large business without a plan is like trying to organize a car rally without a map, not impossible, but difficult.

It has been argued that although there is a general perception and belief that strategic planning improves organization effectiveness, if wrongly pursued the anticipated value may not be tapped. Steiner (1979) points out that a wrong strategy or a wrongly formulated strategy may not translate into the anticipated value for the organization. Other scholars such as Ringbakk (1969), Porter (1985), and, Johnson, Scholes and Whittington (2005) have advanced various explanations as to why strategic planning may not realize the anticipated results. Yavas, Kagnak and Dilber (1985), studying the management climate in the LDCs observed that not communicating firm objectives to lower echelons of management, lack of reliable data and the authoritarian attitude of the managers strongly limits planning participation hence its effectiveness. Mankins and Steele (2005) observed that poorly communicated strategy is one of the causes of poor performance.

It has also been argued that separating strategy formulation from strategy implementation is one of the possible reasons for non-achievement of the expected results. Porter (1985) and Taylor (1995) note that strategy development does not end when implementation starts. The two interrelate and overlaps. The strategic plan formulation stage has to take into account implementation issues such as leadership, culture and resources for purposes of facilitating effective implementation of the strategies and work plans set out. Steiner (1979) observed that many strategic planning systems were 
inappropriate because they failed to link planning and resource allocation, affecting strategy implementation. Ringbakk (1969) points out that planning fails in situations where it has not been integrated into a company's total management systems. It ought to be treated as part and parcel of such a system.

This implies that if strategic planning is viewed as separate and distinct from the process of management, its anticipated value to the organization may not be realized. Tourangeau (1987) shares these sentiments but cautions that strategic business planning cannot be expected to cure all that ails an organization i.e. address other shortcoming of the management process, but can best be seen as a partial solution to management problems. Strategic planning, or any other management technique is of limited value by itself, only a partnership with all parts of the management particularly execution, controls and rewards can result in synergy and lead to substantial advancement.

Johnson, Scholes and Whittington (2005), note that strategic drift occurs when the organization's strategy gradually moves away from relevance to the forces at work in its environment. Sharing this view, Thompson, Strickland and Gamble (2007) provide a caution that granted good strategy combined with good strategy execution doesn't guarantee that a company will avoid periods of sub-par performance because there are shifts in market conditions and internal miscues. In their survey to see how successful companies translates their strategies into performance, Mankins and Steele (2005) observed that companies typically realize only about 60 percent of their strategies potential value because of defects and breakdowns in planning and execution.

Hofer and Schendel (1978) argue that strategy is important and therefore its formulation should be managed and not left to chance. It is not how completely a strategy is stated that alone determine success, its internal consistency, the insight and creativity displayed, and its implementation all contribute more to successful strategies. However, it needs to be carefully described to remove unnecessary risks of inconsistency and misunderstanding. Formal strategic planning seems to provide the rational and analytical approach towards addressing this concern. Although the link between strategic planning and firm performance is not empirically conclusive, it is nevertheless a tool that can be utilized towards enhancing organizational effectiveness.

Greenley (1986) examining empirical data from nine surveys ( 8 in USA and 1 UK within the manufacturing business) on the relationship between strategic planning and company overall performance noted mixed conclusions with five studies concluding the existence of the relationship while the rest conclude that higher levels of performance did not necessarily relate to the utilization of strategic planning.

Miller and Cardinal (1994) employed a meta-analytic approach using data from 26 previously published studies and concluded that strategic 
planning positively influences organization performance. Caeldries and VanDierdonck (1988) surveyed 82 Belgian Business Organizations and reported a link between strategy and performance. They noted that strategy enables an organization to strengthen its competitive position, and facilitates integration and coordination of members' behavior. Pealtie (1993) observed that the main reason for the introduction of formalized strategic planning is to improve organization performance through the development and implementation of better strategies. Pealtie noted that managing a large business without a plan is like trying to organize a car rally without a map, not impossible, but difficult.

Published research from Africa also indicates that strategic planning is an effective tool in improving organization performance. Imoisili (1978), studying indigenous and multinational companies in Nigeria, concluded that the more effective companies are found among organizations which maintain consistency between environmental perception and management practices, do long-term planning, use more flexible control systems and have smaller spans of control. Fubara (1986) did a survey in Nigeria and observed that companies that engage in formal planning experienced growth in profits.

It has been argued that although there is a general perception and belief that strategic planning improves organization effectiveness, if wrongly pursued the anticipated value may not be tapped. Steiner (1979) points out that a wrong strategy or a wrongly formulated strategy may not translate into the anticipated value for the organization. Johnson, Scholes and Whittington (2005), note that strategic drift occurs when the organization's strategy gradually moves away from relevance to the forces at work in its environment. Tourangeau (1987) shares these sentiments but cautions that strategic business planning cannot be expected to cure all that ails an organization i.e. address other shortcoming of the management process, but can best be seen as a partial solution to management problems. Strategic planning, or any other management technique is of limited value by itself, only a partnership with all parts of the management particularly execution, controls and rewards can result in synergy and lead to substantial advancement.

In their survey to see how successful companies translates their strategies into performance, Mankins and Steele (2005) observed that companies typically realize only about 60 percent of their strategies potential value because of defects and breakdowns in planning and execution. Hofer and Schendel (1978) argue that strategy is important and therefore its formulation should be managed and not left to chance. Therefore, each of the stages in the strategic planning process cannot be taken for granted. 


\section{Methodology}

\subsection{Research Design and Method}

The main objective of this research was to assess strategic planning and its contribution on the performance of the organizations. To achieve this objective, descriptive type of research was employed in Dire Dawa National Cement. Zikmund, W. G. (2003) indicated that descriptive type of research design helps to depict accurately the characteristics of a particular individual, situation and group. An intense and comprehensive study was conducted on the strategic planning practices in the organization in relation to organizational performance.

The research method is considered to be very effective in answering research questions by using quantitative and qualitative approaches. "A quantitative variable is a numerical attribute of an individual or object (Collis \& Hussey, 2003). Quantitative approaches analysis numbers and figures which are suitable for measuring human behavior. Qualitative studies base their accounts on qualitative information (words, sentences and narratives). Therefore, using both methods the researcher capitalized the strength of qualitative and quantitative approaches by removing any biases that exist in single research approach.

\subsection{Data Type and Sources of Data}

Primary and secondary data sources were used in this study where data was obtained through questionnaires (for all top, middle and line level managers of the company) and an interactive interview (for both the CEO and deputy CEO of the company who is also the head of planning and monitoring department of the company). According to Mugenda and Mugenda (2008), primary data refers to data that the researcher collects from respondents while secondary data refers to data from other sources like records and documents, thus primary data was considered more reliable and up to date.

\subsection{Data Collection Tools}

The main instrument of data collection in this study were questionnaires (for all top, middle and line level managers of the company) and an interactive interview (for the CEO and deputy CEO who is also the department head of planning and monitoring of the company). In the course of conducting the study, the researcher distributed 65 copies of questionnaires for the top, middle and line level managers of the company who are working in the company. All the 65 questionnaires were completed and collected which makes $100 \%$ response rate. Besides, Interviews were held with 2 top level management officials (with the CEO and deputy CEO of the company who is also the department head of planning and monitoring department of the company) from the company. 
Semi-structured type of interview used in the research evaluation by the researcher. In semi-structured interviews, emphasis was on obtaining answers to carefully phrased questions the interviewers sought to encourage free and open responses, and this allowed a trade-off between comprehensive coverage of topics and in-depth exploration of a more limited set of questions. Patton (2002) asserts that, the quality of the information obtained through this method is largely dependent on the interviewer's skills and personality. Indepth interviews also encourage capturing of respondents' perceptions in their own words, a very desirable strategy in qualitative data collection. In this study data was collected from Human Resource Management senior staff, Finance Department, ICT Department, Supply Chain Department, General Service, Marketing \&Sales Department, Production and Operation Department, Mechanical Maintenance Department, Electrical Maintenance Department, Query and Auto-Garage, Quality Control, Safety and Engineering Department.

\subsection{Sampling and Sample Size Determination}

This study was tested using purposive sampling technique which involves examining the entire top, middle and line level management population. The main reason for this was that according to the planning and monitoring department official of the company, the employees who participate in the designing, monitoring \& evaluation and implementation process of the strategic plan of the company were the top, middle and line level managers.

The study population were 65 different level managers of the organization and identified 24 top level managers and 41 middle and line level managers, a total of 65 , which is all of the top, middle and line level managers of the organization, were considered for the study.

\subsection{Data Analysis and Interpretation}

The nature of data collected were qualitative and quantitative and were therefore analyzed using content analysis technique. The quantitative data that was collected through questionnaires was analyzed by descriptive statistical method (using Excel) as frequency to indicate percentage of respondents on which the researcher concluded the findings.

The qualitative data were therefore analyzed using content analysis technique. Through content analysis, responses from different respondents were compared and summarized according to the objectives of the study. Content analysis was a tool for measuring the content of information. Its objective was to obtain a qualitative description of the manifest content of communication (Robinson, 2003). It was suitable because of its flexibility and allows for objectivity (Cooper \& Schindler, 2008). The data presentation was set using tables and charts to make clear understanding. 


\section{Data Presentation, Analysis and Interpretation}

\subsection{Demographic Profile of the Respondents}

The background of characteristics of respondents as referred in this section deals with the presentation on the overview and number of respondents who filled the questionnaire for the study. This part gives general information about respondents like gender, age, years of experience and educational level. Gender: 91\% (59) of the respondents are male and the rest 9\% (6) of the respondents are female

Age: the majority of employees 48\% (31) are between the age 27-35 and the rest are in the age category ranging from 18-26 (9\%), 36-44 (26\%), and $\geq 45$ (17\%).

Experience: $45 \%$ (29) had adequate work experience of 6-9 years. It also shows that $37 \%$ (24) of the employees have served the factory more than 10 years, $17 \%$ (11) respondents served 2-5 years and $2 \%$ (1) respondents have served less than 2 years respectively.

Educational Level: Diploma graduate constitute 8\% (5), degree holders are $82 \%$ (53) and Master holders are 11\% (7).

Level of Management: $63 \%$ (41) are Middle and line managers (operational level workers) and the remaining 37\% (24) are Top level managers.

\subsection{Awareness and Context of Strategic Planning}

This section presents data relating to respondents' awareness about strategic planning before its design and implementation. More specifically, this section presents facts such as method of getting awareness, the momentums that have led to the design and implementation of the plan in the selected levels, experts who have participated in the course of developing the plan and the plan's time scope. See Table 4.1 below.

Table 4.1: Awareness and Context of Strategic Planning

\begin{tabular}{|c|c|c|c|c|}
\hline No & Item & Respondent Category & Frequency & Percentage \\
\hline \multirow[t]{2}{*}{1} & \multirow{2}{*}{$\begin{array}{l}\text { Existence/presence of } \\
\text { Strategic Plan }\end{array}$} & Yes & 65 & $100 \%$ \\
\hline & & No & 0 & $0 \%$ \\
\hline \multirow[t]{2}{*}{2} & \multirow{2}{*}{$\begin{array}{l}\text { Awareness about } \\
\text { Strategic Plan }\end{array}$} & Yes & 57 & $88 \%$ \\
\hline & & No & 8 & $12 \%$ \\
\hline \multirow[t]{4}{*}{3} & \multirow{4}{*}{$\begin{array}{l}\text { Method of getting } \\
\text { awareness }\end{array}$} & Management Development Program & 23 & $40.4 \%$ \\
\hline & & $\begin{array}{l}\text { Specialized training (short-term } \\
\text { training conducted to implement } \\
\text { strategic plan) }\end{array}$ & 26 & $45.6 \%$ \\
\hline & & Formal education & 4 & $7 \%$ \\
\hline & & Any other & 4 & $7 \%$ \\
\hline \multirow[t]{3}{*}{4} & \multirow{3}{*}{$\begin{array}{l}\text { Factors led to the } \\
\text { adoption and } \\
\text { implementation of } \\
\text { Strategic Plan }\end{array}$} & Poor performance of the factory & 45 & $69 \%$ \\
\hline & & Top-level management initiative & 15 & $23 \%$ \\
\hline & & $\begin{array}{l}\text { Leveraging good performing } \\
\text { organizations that have implemented it }\end{array}$ & 5 & $8 \%$ \\
\hline
\end{tabular}




\begin{tabular}{|c|c|c|c|c|}
\hline & & Policy direction & 0 & $0 \%$ \\
\hline & & Any other & 0 & $0 \%$ \\
\hline \multirow{5}{*}{5} & \multirow{5}{*}{$\begin{array}{l}\text { Experts who participated } \\
\text { in the development of } \\
\text { Strategic Plans }\end{array}$} & A strategic planning committee & 5 & $8 \%$ \\
\hline & & Centralized planning unit & 6 & $9 \%$ \\
\hline & & Employees & 8 & $12 \%$ \\
\hline & & Different managerial levels & 46 & $71 \%$ \\
\hline & & Any other & 0 & $0 \%$ \\
\hline \multirow[t]{4}{*}{6} & \multirow{4}{*}{$\begin{array}{l}\text { Duration } \\
\text { Strategic Plan }\end{array}$} & $1-3$ years & 51 & $78 \%$ \\
\hline & & $3-6$ years & 10 & $15 \%$ \\
\hline & & $6-9$ years & 1 & $2 \%$ \\
\hline & & 9 years or more & 3 & $5 \%$ \\
\hline
\end{tabular}

Source: Author Compilation, 2018

As it is indicated in the Table 4.1 above, all of the respondents $100 \%$ (65) knew about the existence/presence of strategic plan in their organization. And the majority of the respondents $88 \%$ (57) were aware about strategic planning before its implementation while the remaining $12 \%$ (8) did not get early awareness about strategic planning purpose, process and success. It is possible to infer from this fact that though most of the managers might have been provided awareness about the essence of strategic planning, there might have also been a gap in addressing all the managers of the sectors engaged in the process.

Besides, Table 4.1 also presents that from among the respondents who stated that they have had awareness about strategic planning before its implementation, majority of the respondents $40.4 \%$ (23) and $45.6 \%$ got awareness through Management Development Program and specialized training (short-term training) respectively conducted to implement strategic plan. In this regard, insignificant number of respondents stated that they have had awareness through formal education 7\% (4) and through other related trainings (7\%) like, participating in the designing and preparation of the strategic plan, through participating in the implementation of the strategic plan and one participant didn't has given the awareness about the strategic plan of the factory. From the facts presented above it is possible to deduce that the sectors did have proactive preparation to design and implement the strategic planning for which preparing the employees through specialized training and management development program and education might have been the requirements.

Moreover, in addressing the question raised to identify the momentums that have led to the adoption of the strategic planning, majority of the respondents $69 \%$ (45) stated that the adoption factor was the poor performance of the factory. However, a good number of respondents $23 \%$ (15) stated that it has been the top level management initiative that has led 
to the design and implement the plan. This may backup the reason why the factory did make proactive preparation to design and implement the strategic planning. Hence, it can be said that the approach employed in the course of adopting the plan was the top-down one.

Furthermore, Table 4.1 presents that in the course of designing the Strategic Planning, the majority of the respondents $71 \%$ (46) argued that only the top, middle and line level managers were participated. Few of the respondents stated that it has been made by strategic planning committee, centralized planning unit and employees. This implies that the plan was made at the center and was not participatory. Hence, it is possible to conclude that the planning process did not involve the major stakeholders.

Finally, Table 4.1 above indicates that respondents do have different level of understanding with regard to the time coverage of the strategic Planning. In this regard, the majority of the respondents $78 \%$ (51) have clear understanding about the time scope of the Plan. However, it has been stated that insignificant number of respondents lack such an understanding. From this fact, it is possible to deduce that having clear understanding about the time coverage of the strategic planning would help the implementers to comply with the requirements at different level of the plan execution thereby making timely reports on the progress.

\subsection{Environmental Scanning}

Once the vision and mission are clearly identified, the organization must analyze its external and internal environment, (Lynch, 2000). The environmental scan, performed within the frameworks of the Five Forces Model and SWOT, analyzes information about organization's external environment (economic, social, demographic, political, legal, technological, and international factors), the industry, and internal organizational factors. To this effect, hereunder, data pertaining to the environmental scanning process (including both internal and external) are be presented and discussed.

\subsubsection{Internal \& External Environmental Analysis}

There are many factors listed in the literature that influence strategic planning process. Environmental uncertainties hampers the development of long range plans; scarce resources strategic planning should be aligned to use scarce resources effectively; legal forces legislative changes introduce new dynamics in an industry thus affecting strategic planning; size and complexity of an organization - as size and complexity of an organization increases, so does the degree of formulating of planning activities; the extent of involvement in operating issues compromises the attention paid to management functions; the implementation gap - this is the inability of the 
top management and the planners to effectively communicate with the planners; the lifecycle of the organization - as organizations move through different phases, the competitive environment changes and influences the way they plan and execute strategy (Thompson, et al, 2007).

Organizations need to plan for a number of reasons. These are: to reorient the organization or institution to the needs of the community; another serious consideration is that when people plan for expansion, a certain level of minimum standard must be observed. This will guarantee a certain level of minimum quality performance. Effective strategic planning initiatives make organizations more responsive and viable instrument for socio-economic development (Robinson and Pearce, 1983). Strategic planning is a continuous process that requires constant feedback about how the current strategies are working.

Therefore, organizations should scan their internal and external environments to identify weaknesses and strengths from inside and the threats and opportunities in the external environment. The following Table 4.2 presents the practices of internal \& external environmental analysis in the selected factory.

Table 4.2: Internal \& External Environmental Analysis

\begin{tabular}{|c|c|c|c|c|c|}
\hline Items & $\begin{array}{l}\text { Strongly } \\
\text { Disagree } \\
\text { in \% }\end{array}$ & $\begin{array}{l}\text { Disagree } \\
\text { in } \%\end{array}$ & $\begin{array}{l}\text { Neutral } \\
\text { in } \%\end{array}$ & $\begin{array}{l}\text { Agree } \\
\text { in } \%\end{array}$ & $\begin{array}{l}\text { Strongly } \\
\text { Agree in } \\
\%\end{array}$ \\
\hline \multicolumn{6}{|c|}{ Environmental Scanning (Internal and External): } \\
\hline $\begin{array}{l}\text { There have been formal mechanisms to scan the } \\
\text { organizations internal and external environment }\end{array}$ & $5 \%$ & $8 \%$ & $25 \%$ & $49 \%$ & $13 \%$ \\
\hline The organization had bench mark scanning & $3 \%$ & $6 \%$ & $14 \%$ & $63 \%$ & $14 \%$ \\
\hline $\begin{array}{l}\text { The organization had } \\
\text { identified/conducted both its Strength and } \\
\text { Weakness analysis to develop its strategic plan }\end{array}$ & $0 \%$ & $5 \%$ & $14 \%$ & $49 \%$ & $32 \%$ \\
\hline $\begin{array}{l}\text { Both threats and opportunities were scanned to } \\
\text { develop strategic plan of the organization }\end{array}$ & $0 \%$ & $5 \%$ & $17 \%$ & $54 \%$ & $25 \%$ \\
\hline
\end{tabular}

Source: Author Compilation, 2018

Note: Strongly Disagree (the corresponding value is 1), Disagree (the corresponding value is 2), Neutral (the corresponding value is 3 ), Agree (the corresponding value is 4) and Strongly Agree (the corresponding value is 5).

Table 4.2 presents that majority of the respondents were asked whether their organizations had formal mechanisms for internal \& external environmental analysis in the pre-strategic planning period. In this regard, majority of the respondents $49 \%$ and $13 \%$ agreed and strongly agreed respectively $(62 \%)$ that the company had formal mechanisms to analyze their internal \& external environments. However, though it is not significant number, some respondents discontent the concern that their respective organizations had formal mechanisms for examining their internal 
(operational) \& external environment. This may infer that the company have internal (operational) \& external mechanisms including rules and guidelines to examine their internal environment.

Besides, Table 4.2 presents that majority of the respondents $63 \%$ and $14 \%$ agreed and strongly agreed respectively (77\%) on the fact that the benchmark scanning has been made before the design and implementation of the strategic planning in their respective sectors where the plan has been executed. However, the table also indicates that few of the respondents $(3 \%)$ strongly disagree with the idea that the organization had conducted the benchmark analysis prior to the design and implementation of the plan. This implies that the factory might have had some other organizations to learn from prior to the design and implementation of strategic planning in their respective organizations.

In this regard, the respondents were also asked whether their company organizations have identified and conducted strength and weakness analysis prior to the design and implementation of the plan. To this effect, the overwhelming number of respondents $49 \%$ and $32 \%$ agreed and strongly agreed respectively $(81 \%)$ that strength and weakness analysis have been identified and conducted which preceded the design and execution of the plan. Hence, it can be argued that despite the fact that the plan is instructed from the top, the organizations have made attempt to examine their internal \& external environment which might have helped them to internalize the process of designing and implementing the strategic plan. The respondents were asked to rate the identification of both weaknesses and strengths of the organization prior to the design of the plan. As it is stated in the Table 4.3 above most of the respondents agreed that the sectors have identified their strengths and weaknesses.

Respondents were also asked whether their respective company have scanned threats and opportunity analysis in their immediate external environments. In this regard, a majority number of respondents $54 \%$ and $25 \%$ agreed and strongly agreed respectively (79\%) that the company have scanned the external environment in order to identify possible threats and opportunities. Besides, the respondents agreed that the organizations have formal mechanisms to analyze the external environment.

The above presented facts show that the sectors had a good practice of examining their respective internal \& external environments prior to the design of strategic planning. Besides, the facts also imply that there have been formal mechanisms that require the organizations to examine and analyze the internal \& external environments that offer them opportunities or impose threats on their operations. 


\subsection{Organizational Mission, Vision, Objectives, Goals and Values}

The following section presents the processes, practices and stakeholders in the course of determining organizational values in the selected sectors. See Table 4.3 below:

Table 4.3: Organizational Mission, Vision, Objectives, Goals and Values

\begin{tabular}{|l|l|l|l|l|l|}
\hline \multicolumn{7}{|l|}{} & $\begin{array}{l}\text { Strongly } \\
\text { Disagree } \\
\text { in \% }\end{array}$ & $\begin{array}{l}\text { Disagree } \\
\text { in \% }\end{array}$ & $\begin{array}{l}\text { Neutral } \\
\text { in \% }\end{array}$ & $\begin{array}{l}\text { Agree } \\
\text { in \% }\end{array}$ & $\begin{array}{l}\text { Strongly } \\
\text { Agree in } \\
\%\end{array}$ \\
\hline Mission, Vision, Organizational Objectives, Goals and Values Statement: & \multicolumn{3}{l|}{} \\
\hline $\begin{array}{l}\text { Organizational mission and vision statements were } \\
\text { clearly stated }\end{array}$ & $0 \%$ & $3 \%$ & $7 \%$ & $55 \%$ & $35 \%$ \\
\hline $\begin{array}{l}\text { The mission is long-term in nature and shows the } \\
\text { organizations ambitions }\end{array}$ & $0 \%$ & $5 \%$ & $5 \%$ & $52 \%$ & $38 \%$ \\
\hline $\begin{array}{l}\text { Awareness has been created to employees on the } \\
\text { mission and vision statement of the organization }\end{array}$ & $3 \%$ & $8 \%$ & $14 \%$ & $46 \%$ & $29 \%$ \\
\hline The organization has formalized the mission statement & $0 \%$ & $5 \%$ & $9 \%$ & $55 \%$ & $31 \%$ \\
\hline Statement of goals and objectives were designed & $0 \%$ & $3 \%$ & $15 \%$ & $55 \%$ & $26 \%$ \\
\hline $\begin{array}{l}\text { Both short-term and long-term } \\
\text { objectives were spelt out }\end{array}$ & $0 \%$ & $5 \%$ & $8 \%$ & $49 \%$ & $38 \%$ \\
\hline $\begin{array}{l}\text { The organization updates/revise its goals, objectives and } \\
\text { values continuously }\end{array}$ & $2 \%$ & $6 \%$ & $8 \%$ & $60 \%$ & $25 \%$ \\
\hline $\begin{array}{l}\text { Objectives are SMART (Specific, Measurable, } \\
\text { Attainable, Rewardable, and Timely bounded) }\end{array}$ & $0 \%$ & $6 \%$ & $14 \%$ & $49 \%$ & $31 \%$ \\
\hline $\begin{array}{l}\text { Employees are participated on the development of the } \\
\text { mission, vision, objectives and goals of the } \\
\text { organization }\end{array}$ & $5 \%$ & $8 \%$ & $32 \%$ & $43 \%$ & $12 \%$ \\
\hline Statement of Values were designed & $2 \%$ & $6 \%$ & $32 \%$ & $48 \%$ & $12 \%$ \\
\hline
\end{tabular}

Source: Author Compilation, 2018

Table 4.3 above presents that the overwhelming number of respondents $55 \%$ and $35 \%$ agreed and strongly agreed respectively (90\%) that the organizations have stated the mission \& vision statements. In this regard, the respondents' position towards this particular item is positive. Similarly, overwhelming number of respondents 52\% and $38 \%$ agreed and strongly agreed respectively (90\%) that the company has stated long-term mission statements.

As it is presented in the Table 4.3 above, the majority of respondents $46 \%$ and $29 \%$ agreed and strongly agreed $(75 \%)$ that an awareness has been created to employees on the mission and vision statement of the organization. More so, the table also shows that the majority of the respondents 55\% and $31 \%$ agreed and strongly agreed respectively (86\%)and hold that the company have formalized the mission statements.

From Table 4.3 above, it is possible to infer that sectors which have undergone the design and implementation of the strategic planning had their respective organizational mission \& vision statements with long-term 
perspective. And also the organizations had not limitation on creating awareness on the mission \& vision statements designed. Moreover, it is also possible to infer that as the organizations have formalized their mission statements, this might have helped them to monitor their progress.

The fifth item in the Table 4.3 above is about organizational goals and objectives. In line with this, most of the respondents 55\% and 26\% agreed and strongly agreed respectively $(81 \%)$ agreed that the company have established its goals and objectives. the Table also illustrates that $49 \%$ and $38 \%$ of the respondents agreed and strongly agreed respectively $(87 \%)$ that the company's goals and objectives were clearly stated as short-term and long-term in terms of their scope. Similarly, the overwhelming number of respondents $60 \%$ and $25 \%$ agreed and strongly agreed respectively (85\%) that the company updates/revise its goals, objectives and values continuously. The data also shows that the most of the respondents $49 \%$ and $31 \%$ agreed and strongly agreed (80\%) that the company's objectives are SMART (Specific, Measurable, Attainable, Rewardable, and Timely bounded).

The data also depicts that $43 \%$ and $12 \%$ of respondents agreed and strongly agreed respectively (55\%) that there is a significant number of employee participation on the development of the mission, vision, objectives and goals of the company. A significant number of respondents (32\%) also hold a neutral position whether employees did participate on the development of the mission, vision, objectives and goals of the company. Most of the respondents $48 \%$ and 12\% agreed and strongly agreed respectively (60\%) that the company statement of values were designed.

Generally, the facts presented in the Table 4.3 above imply that the company's department and divisions values at middle level are the reflections of the value statement of the company. Hence, there is high room to design organizational values that are initiated by the departments and divisions. This may positively affect the capacity of the company to accommodate peculiar issues that may require different perspective. However, it is also possible to say that cascading similar values to middle level may help to achieve uniformity and parallel development.

\subsection{The Designing of Strategic Planning}

This section presents issues relating to the designing of strategic planning. In this regard, 58\% and $17 \%$ of respondents agreed and strongly agreed respectively (75\%) that different stakeholders (such as suppliers, customers, and etc.) have participated in the design and development of the company's strategic plan. Significant number of respondents $18 \%$ hold a neutral position regarding this. This shows that the organizations did involve the larger stakeholders in the course of designing the plan. This also implies 
that the large base of the plan. The data also shows that there is a wide $(55 \%$ and $20 \%$ of respondents agreed and strongly agreed respectively $(75 \%)$ that employee's participation in the design and development of the company's strategic plan. In addition, 43\%and 14\% agreed and strongly agreed respectively $(57 \%)$ that with regard to the adequacy of the budget allocated for the implementation of the plan. Significant number of respondents $37 \%$ also hold a neutral position regarding this. The information collected from the key informants indicates that there is a gap in the adequacy budget allocation for the implementation of the plan and it was the result of poor financial planning by the company.

Regardless of this, the data indicate that the results of the plan were clearly spelt out. This is shown by the large number of respondents $54 \%$ and $32 \%$ of respondents agreed and strongly agreed respectively $(86 \%)$ that the results of strategic planning process were clearly spell out- what will be done, how will be done, when will be done and by whom will be done. The facts also indicate that there is clear division of labor. The data also indicates that even if more respondents $35 \%$ and $28 \%$ agreed and strongly agreed respectively $(63 \%)$ that possible risks were forecasted, but also $29 \%$ of respondents hold a neutral position on this item. The data also shows that $46 \%$ and $23 \%$ of respondents agreed and strongly agreed respectively (69\%) also that long-term positive implications were scanned, and significant number of respondents $26 \%$ hold a neutral position on this item. The data also indicates that $38 \%$ and $22 \%$ of respondents agreed and strongly agreed respectively $(60 \%)$ that best alternative strategies were selected while adopting the organizations strategic plan, also $31 \%$ of respondents hold a neutral position on this item. Finally, the data shows that equal number of respondents $34 \%$ agreed and also hold a neutral position respectively that there has been alignment between strategic planning and reforms like BPR, BSC and change army.

Furthermore, the key informants have explained the strategic plan to be a framework and BPR, BSC and Change Army as tools to implement it. They further stated that the BPR is employed to identify what is to be done, the BSC deals with how it is to be done and the change army is about who is to do the job.

From the facts presented above it is possible to infer that the alignment between strategic planning and the reform tools, may help the implementers to consider the organizational values in the course of implementing the plan. This may also keep the implementers on the right track gearing towards the attainment of the pre-established goals. Furthermore, it is possible to infer that these alignments contribute towards simplifying the process of plan implementation. See Table 4.4 below: 
Table 4.4: The Design of Strategic Plan

\begin{tabular}{|l|l|l|l|l|l|l|}
\hline \multicolumn{5}{|l|}{} \\
Item & $\begin{array}{l}\text { Strongly } \\
\text { Disagre } \\
\text { in \% }\end{array}$ & $\begin{array}{l}\text { Disagree } \\
\text { in \% }\end{array}$ & $\begin{array}{l}\text { Neutral } \\
\text { in \% }\end{array}$ & $\begin{array}{l}\text { Agree } \\
\text { in \% }\end{array}$ & $\begin{array}{l}\text { Strongly } \\
\text { Agree in } \\
\%\end{array}$ \\
\hline Designing Strategic Planning \\
$\begin{array}{l}\text { Different stakeholders have participated in the } \\
\text { development of the organizations strategic planning }\end{array}$ & $2 \%$ & $5 \%$ & $18 \%$ & $58 \%$ & $17 \%$ \\
\hline $\begin{array}{l}\text { There is employees participation in the development } \\
\text { of the organizations strategic planning }\end{array}$ & $0 \%$ & $8 \%$ & $17 \%$ & $55 \%$ & $20 \%$ \\
\hline The required budgets were put on spot & $2 \%$ & $5 \%$ & $37 \%$ & $43 \%$ & $14 \%$ \\
\hline $\begin{array}{l}\text { The results of strategic planning process were clearly } \\
\text { spell out- what will be done, how will be done, when } \\
\text { will be done and by whom will be done. }\end{array}$ & $0 \%$ & $3 \%$ & $11 \%$ & $54 \%$ & $32 \%$ \\
\hline Possible risks were forecasted positive implications were & $0 \%$ & $5 \%$ & $26 \%$ & $46 \%$ & $23 \%$ \\
\hline $\begin{array}{l}\text { Long-term } \\
\text { scanned }\end{array}$ & $0 \%$ & $8 \%$ & $29 \%$ & $35 \%$ & $28 \%$ \\
\hline $\begin{array}{l}\text { Best alternative strategies were selected while } \\
\text { adopting the organizations strategic planning }\end{array}$ & $0 \%$ & $9 \%$ & $31 \%$ & $38 \%$ & $22 \%$ \\
\hline $\begin{array}{l}\text { The organizations strategic planning was aligned with } \\
\text { reforms (like the BPR, BSC and change army) }\end{array}$ & $5 \%$ & $14 \%$ & $34 \%$ & $34 \%$ & $14 \%$ \\
\hline
\end{tabular}

Source: Author Compilation, 2018

\subsection{Implementation of the Plan}

Hereunder, issues relating to the implementation of strategic planning are presented in the following Table 4.5.

Table 4.5: Implementation of the plan

\begin{tabular}{|c|c|c|c|c|c|}
\hline Item & $\begin{array}{l}\text { Strongly } \\
\text { Disagree } \\
\text { in \% }\end{array}$ & $\begin{array}{l}\text { Disagree } \\
\text { in } \%\end{array}$ & $\begin{array}{l}\text { Neutra } \\
1 \text { in } \%\end{array}$ & $\begin{array}{l}\text { Agree } \\
\text { in } \%\end{array}$ & $\begin{array}{l}\text { Strongly } \\
\text { Agree in } \\
\%\end{array}$ \\
\hline \multicolumn{6}{|l|}{ Implementation of the Plan: } \\
\hline $\begin{array}{l}\text { The right unit has been created and authorized for } \\
\text { implementation }\end{array}$ & $2 \%$ & $4 \%$ & $31 \%$ & $48 \%$ & $15 \%$ \\
\hline $\begin{array}{l}\text { Required resources were put on spot (like Financial } \\
\text { Resources, Human Resources and etc). }\end{array}$ & $0 \%$ & $6 \%$ & $17 \%$ & $66 \%$ & $11 \%$ \\
\hline $\begin{array}{l}\text { The plan was broken down into short term \& } \\
\text { medium term time period }\end{array}$ & $0 \%$ & $5 \%$ & $15 \%$ & $62 \%$ & $18 \%$ \\
\hline $\begin{array}{l}\text { The activities to implement the strategic plan were } \\
\text { aligned with the organization strategy }\end{array}$ & $0 \%$ & $5 \%$ & $12 \%$ & $63 \%$ & $20 \%$ \\
\hline
\end{tabular}

Source: Author Compilation, 2018

Table 4.5 above presents that different units were established for the purpose of plan implementation. This is indicated by the overall position of the respondents that account for $48 \%$ and $15 \%$ agreed and strongly agreed respectively (63\%) supporting the idea that units were established, but also significant number of employees $31 \%$ also held to neutral position on this matter. $66 \%$ and $11 \%$ of respondents agreed and strongly agreed respectively 
(77\%) that the required resources were put on spot/made available (like Financial Resources, Human Resources and etc.) for the purpose of implementing the strategic plan implementation of the company.

On the other hand, most of the respondents $62 \%$ and $18 \%$ agreed and strongly agreed respectively $(80 \%)$ that the plan was broken down into parts for simplifying implementation. Besides, most of the respondents agreed that activities to implement the strategic plan were aligned with the company's strategy (indicated in the $63 \%$ and $20 \%$ of respondents agreed and strongly agreed respectively ( $83 \%$ ) that activities were aligned with strategy).

The facts presented above imply that as a result of establishing specific units, it might have been possible to clarify the line of authority and accountability. Moreover, it is possible to infer from Table 4.5 above that there has been good practice in terms of breaking the plan in to short-term and medium, aligning activities with the strategy and authorizing the implementing agencies established.

\subsection{Monitoring and Evaluation of Strategic Plan}

Table 4.6: Monitoring and Evaluation of Strategic Plan

\begin{tabular}{|c|c|c|c|c|c|}
\hline Items & $\begin{array}{l}\text { Strongly } \\
\text { Disagree } \\
\text { in \% }\end{array}$ & $\begin{array}{l}\text { Disagree } \\
\text { in } \%\end{array}$ & $\begin{array}{l}\text { Neutral } \\
\text { in } \%\end{array}$ & $\begin{array}{l}\text { Agree } \\
\text { in } \%\end{array}$ & $\begin{array}{l}\text { Strongly } \\
\text { Agree in } \\
\%\end{array}$ \\
\hline \multicolumn{6}{|l|}{ Monitoring and Evaluation: } \\
\hline $\begin{array}{l}\text { Strategic plans suitable to } \\
\text { organizational objectives and goals }\end{array}$ & $0 \%$ & $3 \%$ & $14 \%$ & $51 \%$ & $32 \%$ \\
\hline $\begin{array}{l}\text { Participatory oversight has been } \\
\text { made during implementation }\end{array}$ & $0 \%$ & $3 \%$ & $14 \%$ & $54 \%$ & $29 \%$ \\
\hline $\begin{array}{l}\text { There is continuous review and } \\
\text { evaluation of the strategic plan }\end{array}$ & $2 \%$ & $3 \%$ & $12 \%$ & $54 \%$ & $29 \%$ \\
\hline $\begin{array}{l}\text { Clear and valid performance } \\
\text { indicators are put in place }\end{array}$ & $0 \%$ & $6 \%$ & $14 \%$ & $49 \%$ & $31 \%$ \\
\hline $\begin{array}{l}\text { All employees held accountable for } \\
\text { the implementation of the } \\
\text { organizations strategic plan }\end{array}$ & $0 \%$ & $6 \%$ & $20 \%$ & $57 \%$ & $17 \%$ \\
\hline $\begin{array}{l}\text { The good performed employees } \\
\text { were rewarded }\end{array}$ & $0 \%$ & $3 \%$ & $9 \%$ & $45 \%$ & $43 \%$ \\
\hline
\end{tabular}

Source: Author Compilation, 2018

As indicated in Table 4.6 above, the majority of respondents $51 \%$ and $32 \%$ agreed and strongly agreed respectively (83\%) that the company's strategic plan was suitable to organizational objectives and goals. More over the overall rating of the respondents indicated that the level of participatory over sighting while implementing the plan was high. This is evidenced by the number of respondents $54 \%$ and $29 \%$ agreed and strongly agreed respectively $(83 \%)$ that there was participatory over sighting while 
implementing the plan. In addition, the facts presented in the Table 4.6 indicate that good attempt has been made in continuously reviewing and evaluating the plan, putting clear and valid performance indicators and holding the employees accountable.

In spite of this, Table 4.6 above depicts that the company's rewarding scheme for good performing employees found to be fantastic. This might have had positive impacts on the morale of the employees for the efficient implementation of the plan.

Furthermore, the data presented in the Table 4.6 above indicate that the designed and implemented strategic plan was found to be compatible with the overall goals and objectives of the organizations that have undergone the implementation of the plan.

It is possible to deduce that the company have employed the topdown approach in the implementation of the plan which is contradictory with the idea of participatory development. It is also possible to infer that the wonderful rewarding mechanisms might have positively affected the employee motivation which is the central issue in the modern organizations.

\subsection{Strategic Planning and Organizational Performance}

This section presents some of the contributions of the Strategic Planning implementation to organizational performances. Strategic Planning has a number of goals and objectives. In broad terms, Strategic Planning has social, political, economic and technological goals and objectives. However, hereunder, the financial, service efficiency in terms of time and the enhanced need for qualified manpower are mentioned as some of the contributions of strategic planning. See Table 4.7 below:

Table 4.7: Strategic Plan and Organizational Performance

\begin{tabular}{|c|c|c|c|c|c|}
\hline Items & $\begin{array}{l}\text { Strongly } \\
\text { Disagree } \\
\text { in \% }\end{array}$ & $\begin{array}{l}\text { Disagree } \\
\text { in } \%\end{array}$ & $\begin{array}{l}\text { Neutral } \\
\text { in } \%\end{array}$ & $\begin{array}{l}\text { Agree } \\
\text { in } \%\end{array}$ & $\begin{array}{l}\text { Strongly } \\
\text { Agree in } \\
\%\end{array}$ \\
\hline \multicolumn{6}{|c|}{ Monitoring and Evaluation: } \\
\hline $\begin{array}{l}\text { Strategic plans suitable to organizational objectives } \\
\text { and goals }\end{array}$ & $0 \%$ & $3 \%$ & $14 \%$ & $51 \%$ & $32 \%$ \\
\hline $\begin{array}{l}\text { Participatory oversight has been made during } \\
\text { implementation }\end{array}$ & $0 \%$ & $3 \%$ & $14 \%$ & $54 \%$ & $29 \%$ \\
\hline $\begin{array}{l}\text { There is continuous review and evaluation of the } \\
\text { strategic plan }\end{array}$ & $2 \%$ & $3 \%$ & $12 \%$ & $54 \%$ & $29 \%$ \\
\hline $\begin{array}{l}\text { Clear and valid performance indicators are put in } \\
\text { place }\end{array}$ & $0 \%$ & $6 \%$ & $14 \%$ & $49 \%$ & $31 \%$ \\
\hline $\begin{array}{l}\text { All employees held accountable for the } \\
\text { implementation of the organizations strategic plan }\end{array}$ & $0 \%$ & $6 \%$ & $20 \%$ & $57 \%$ & $17 \%$ \\
\hline The good performed employees were rewarded & $0 \%$ & $3 \%$ & $9 \%$ & $45 \%$ & $43 \%$ \\
\hline
\end{tabular}

Source: Author Compilation, 2018 
As it is presented in the Table 4.7 above, the majority of the respondents $53 \%$ and $18 \%$ agreed and strongly agreed respectively (71\%) that implementing the strategic planning resulted in hiring and placing employees based on merit. Likewise, the overall respondent's number implies the existence of hiring and placing employees based on merit. However, it has been evidenced that $20 \%$ of the respondents were neutral concerning whether employment is based on merit. Besides, $9 \%$ of the respondents contend the idea of merit based employment as a result of strategic plan implementation.

With regard to providing the required services within short period of time for the purpose of implementing the strategic planning, the overwhelming numbers of respondents agreed with the idea. Table 4.8 also shows that the respondents $63 \%$ and $14 \%$ agreed and strongly agreed respectively (77\%) that the idea that the company's provision of the required services in a short period of time and also $63 \%$ and $15 \%$ of the respondents agreed and strongly agreed respectively $(78 \%)$ that whether the operational procedures are simplified as a result of strategic plan implementation.

In addition, as it is depicted in the Table 4.8 above, $58 \%$ and $14 \%$ agreed and strongly agreed respectively (72\%) that the service delivery processes are simplified and have become accessible as a result of strategic plan implementation. However, $15 \%$ of respondents disagreed that the service delivery processes are simplified and have become accessible. This shows that there is a gap on service delivery processes of the company in simplifying and making it accessible for the users.

Hofer and Schendel (1978), Henderson (1979), Greenley (1986), Miller and Cardinal (1994) and David (1997) argue that organizations record improved performance once they effectively embrace strategic planning. Carrying out the various steps in the strategic planning process is expected to facilitate the realization of organizational effectiveness and efficient service delivery.

\subsection{Interview addressed by Higher Officials}

\subsubsection{Interview addressed by Planning and Monitoring Department}

The researcher conducted two interviews with the company's highest officials regarding strategic plan of the company and its contribution to organizational performance. One of them is the Strategic planning and Monitoring department head official. He is 45 years old and has first degree in chemical engineering. He is also the deputy CEO of the company. His accountability is to the $\mathrm{CEO}$. He has a lot of duties and responsibilities such as identifying and solving the overall problems of the company, follow-up the overall operations of the company such as focuses on the sales, purchases and fleet operations of the company. However, his ultimate duty and 
responsibility is making sure that the company utilizes its limited resources effectively and efficiently.

The first question forwarded to the concerned official was that whether the company's objectives are SMART. According to the official the company's objectives are specific, measurable, attainable, rewarding and timely bounded. The response of the manager implies that the company gives due attention for their objective for making it easy to understand and implement by the employees in which it can increase the engagement level of employees which in return help the company to achieve its objective. Moreover, His response can be supported by the company's highest percentage of respondents $(80 \%)$ who were participated in this study agreed that their company's objectives are SMART.

The second enquiry was who did participate in the development of the company's Strategic Plans. And the response of the official was that there was participation of Board of Directors, top and middle level management employees and also experts on the area. According to the official, after the strategic plan was developed by the above mentioned bodies, awareness creation and direction was given to all employees about the strategic plan of the company. It implies that strategic plan of NCSC are well filtered and comprehensive but it would be abundant if the company create a means to gather ideas and comments from the entire employee who is to implement the strategic plan so that it will be a good input for the management in formulating its strategic plan to a better degree.

The third query directed to the official was that for how long that your organization has been engaged in the implementation of Strategic Plan. And his response was that the company has been engaged since July 2016 in implementing the strategic plan. The company developed a three years Strategic Plan from 2016/17-2018/19. According to the official there is a tangible difference between before and after the implementation of the strategic plan. It is made clear by the manager that strategic planning helps the company from being less productive to be more productive, as mentioned below NCSC was to totally fail and at the moment, the new management apply strategic plan implementation after formulation, the company has witnessed satisfactory progress.

The fourth question forwarded to the official was to identify the factors that led to the adoption and implementation of Strategic Planning. According to his response the main reasons for the company to adopt its strategic plan were that the company was almost heading to bankruptcy. There was also bad leadership problem that leads the company to a huge debt with long outstanding payments. After the arrival of the new management, the company became productive and also competitive. According to the official, these results were the outcomes of strategic plan implementation. It 
entails that strategic planning for any company is indeed like a mother breast which provide pure milk for a child, which helps a child to grow and also be healthy.

The fifth request was to briefly explain the course/processes of designing the strategic planning of the company. According to the official, the courses/processes of designing the strategic plan was that the company first establishes a team for the development and follow-up of strategic plan. Then design a frame work for its implementation. The next step was to identify the major and tangible problems which needs priority and immediate solution in each department. And finally inculcating the strategy in every departments of the company.

The next question directed to the official was that to pin point who involved and what kind of facilities were availed for the implementation of the organizations strategic planning. The official response was that all employees of the company involves in the implementation of the company's strategic plan. According to him, some of the facilities which were availed for the implementation of the company's strategic plan were allocating some budget/money, changing the industrial culture of the employees through continuous training and also developing performance related pay system in order to inspire and motivate the employees. The manager response denotes that the company use extrinsic reward for motivation, adequate budgeting for each department, employee training and development for facilitating the implementation of strategic planning and these techniques are applied for all the employees as they all expected to implement the strategic planning. However, it will be countless for the company if it uses both intrinsic (such as, sense of achievement, word of praise from seniors, recognition, taking pride from the job and giving work freedom or autonomy) and extrinsic (such as bonus or commission, fringe benefits, improved working conditions, promotion and profit sharing) reward system to motivate poorly performing employees and departments.

The next query was to identify and explain achievements made, challenges faced and opportunities created as a result of Strategic Plan Implementation. The official identifies some of the achievements made: decreasing machine down-time, increases profitability, improves employee attitude, increases employee satisfaction, reduces its cost, there is clear direction towards accountability, responsibility and also transparent standardized procedures in promoting, demoting, and terminating employees. According to the official, the main challenges were shortage of cash/financial constraint and attitude problems. He also states that the company generates its own hard currency by exporting its product to neighboring countries, which is an opportunity for the company. This entails that strategic planning formulation and implementing is not without trials or 
it doesn't mean that the company which implement the strategic planning is relaxed and tranquil as all things are already put in the formulation of strategic plan, but it's meant that more than any other company, those companies that formulate and implement it, will be more profitable and productive in all angle of their business operations.

The other question that was pointed to the deputy $\mathrm{CEO}$ is whether the management follow-up (before and after) the monitoring and evaluation of the organizations strategic plan. And if it did how. According to the deputy CEO, the department conducted thoughtful monitoring and evaluation of the organizations strategic plan. He said that the company has clear and transparent evaluation criteria in order to monitor and evaluate the strategic and operation plan.

Monitoring and evaluation of the strategic and operation plan is cross-checked throughout the top-to-middle and line management level managers including the divisional mangers and also by supervision committee. The supervision team and departments evaluation consists $70 \%$ and $20 \%$ respectively to monitor and evaluate the level manager's performance in order to meet the organizations strategic plan. The supervision leader evaluation constitutes $10 \%$. The management meets every morning to discuss the sales, collection of money. Shipping and invoice and any critical issues that encountered the company. Moreover, in the afternoon the operation deputy CEO meets with the departments to discuss key performance indicators with standard operation procedures. And also they discuss the overall operation and performance (such as the finance, sales, production and transportation) of the company and give an immediate solution for the problems which may arises within the working hour.

Every Monday the whole department meets with the CEO to discuss or evaluates weekly performance of the company. In addition to this, every month the CEO meets with department managers and divisional to evaluate the performance of the company. Every quarter the Board of Directors meets with the department managers and divisional managers to discuss issues/problems that encountered the company. And finally the CEO meets two times a year with all employees of the company to discuss issues that may hamper their activities in the company and solves these issues/problems. The deputy said that the company is the first among its competitors in terms of its strategy, productivity, and utilization. He said that most of the governments big projects bid was won by the company like condominium housing (including 20/80 and 40/60), water projects and road construction. According to the official these were the result of the competitiveness of the company in the market. This shows that the company is well organized and oriented towards what is going on and how it is going, through monitoring and evaluation strategy. It is also can be said that 
strategic planning is not only for executing but also it plays a great role in monitoring and evaluation.

The next inquiry directed to the deputy $\mathrm{CEO}$ was if the strategic plan of the company was aligned with reform (like BSC, BPR, change army). And his response was that the company's reforms was aligned with the company's strategic plan which is a quality circle program in each department through kaizen activities that is to be made up of 5-10 individuals with similar professions come together and discuss and solves issues/problems that encounter the company.

The last question that was directed to the department official is whether the company applies environmental (SWOT) analysis. And if it does, who are the major actors/participants in the scanning and analysis? According to his response the company did apply environmental analysis in activity from consultants, distributors, banks, and from international global cement documents, but lack documenting the environmental scanning and analysis. According to the official the company currently is in the process of documenting the SWOT analysis of the company. From this it can be possible to presume that there is a gap in documenting the company's environmental scanning and analysis which can be considered as the backbone of a strategic plan.

\subsubsection{Interview addressed by the CEO}

The researcher conducted an interview with the company's CEO regarding strategic plan of the company and its contribution to organizational performance. The CEO is 43 years old and has first degree in Electrical engineering. His accountability is to the Board of directors.

The first question forwarded to the CEO was whether the company's objectives are SMART. According to the CEO of the company, the company's objectives are specific, measurable, attainable, rewarding and timely bounded. His response can be supported by the company's highest percentage of respondents who were participated in this study agreed that their company company's objectives are SMART and also by the deputy CEO of the company (who is the head of the company's planning and monitoring department). He affirms the company's objectives are SMART and because of this the company was able to reduce about 55-million-birr last year.

The second query forwarded to the CEO was to firm up the existence of a strategic planning and monitoring department in the company. His reply was an immediate one and said "Absolutely". And the next question in relation with the foregoing request was that why do you need strategic planning department in your organization? According to the CEO, there were so many reasons for the establishment of the department including as 
to setting vision and mission of the company, gap analysis, bench marking, prepare the plan, clarify mandate and scope of work, analyze the internal $\&$ external environment, identify the strategic issues, define the strategic aims, cost the plan and etc. However, the main reason for the company to form the department and make it functional was that the company was almost heading to bankruptcy and limited resources (cash shortage) of the company.

The other enquiry was that to discuss his role or contribution for the effective implementation of the strategic planning of the organization as a CEO of this company. He said that he believes in servant leadership which implies that serving every employee of the company. And after the strategic and operation plan cascaded to department, his role was making sure/confirming every department acquire/secure and utilizes the resources effectively and efficiently the needed resources like human, financial, and raw material resources to accomplish its activities, connecting management and boards. This tells that he plays a pivotal role in mediating between the management and Board of Directors, making sure there is equity and good governance in every departments of the company, creating good relationship between the company and its stakeholders within the country and, as he also state, to abroad, facilitating the technology transfer from foreigners to Ethiopian employees. Generally, it is possible to say that he is ultimately responsible for the failure and success of the company as his work is critical and any mistake he made, will have a great impact on the future of the company.

The next question that was directed to the CEO is whether the company applies environmental (SWOT) analysis. And if it does, who are the major actors/participants in the scanning and analysis? According to his response the company did apply environmental analysis in activity from consultants, customers, distributors, banks, and from international/global cement consumption trend documents, from chemical and construction company, but lack documenting the environmental scanning and analysis. According to the official the company currently is in the process of documenting the SWOT analysis of the company. From this, as mentioned above, it can be possible to presume that there is a gap in the company's environmental scanning and analysis and documenting it.

The last question that was pointed to the CEO is whether the management follow-up (before and after) the monitoring and evaluation of the organizations strategic plan. And if it did how. According to the deputy $\mathrm{CEO}$, the department conducted thoughtful monitoring and evaluation of the organizations strategic plan. He said that the company has a clear and transparent evaluation criterion in order to monitor and evaluate the strategic and operation plan. 
The management meets every morning to discuss the sales, collection of money. Ship and invoice and any critical issues that encountered the company. Moreover, in the afternoon the operation deputy CEO meets with the departments to discuss key performance indicators with standard operation procedures. And also they discuss the overall operation and performance (such as the finance, sales, production and transportation) of the company and give an immediate solution for the problems which may arises within the working hour. Every Monday the whole department including the trade union meets with the CEO to discuss or evaluates weekly performance of the company. In addition to this, every month the CEO meets with department managers and divisional managers including the trade union to evaluate the performance of the company. After two days the monthly meeting did takes place, there is also a cluster meeting between the CEO, deputy CEO and the department managers. Every quarter the Board of Directors meets with the department managers and divisional managers to discuss issues/problems that encountered the company. And finally the CEO meets two times a year with all employees of the company to discuss issues that may hampers their activities in the company and solves these issues/problems.

\section{Summary of Findings, Conclusion and Recommendation 5.1. Summary of Findings}

The study shows that prior to the design of strategic planning in the selected company, overwhelming number of top, middle \& line managers were given awareness about the context and importance of strategic planning in their respective department. However, the results indicate that some employees did not get the awareness in advance.

Though, it has been evidenced that majority of the respondents agreed that the organizations have designed clear organizational values including: vision, mission, goals, objectives and values. Despite this, the respondents had reservation with regard to the level of awareness creation, statements of goals, objectives and values were designed in the course of designing the plan. Moreover, the data collected from the key informants indicated that there has been no room for the employees to design organizational values that are contextual. Rather, the departments in the company are expected to cascade the values of the company in to their respective management levels.

According to the survey data discussed, the majority of respondents $(83 \%)$ agreed that the strategic plan was suitable to organizational objectives and participatory oversight has been made during implementation. The study also shows that there is a gap on whether the strategic plan was suitable to organizational objectives, participatory oversight has been made during 
implementation, clear and valid performance indicators are put in place and also whether all employees held accountable for the implementation of the company's strategic plan. However, majority of the respondents $(83 \%)$ agreed that there has been a continuous review and evaluation process while the plan was being implemented in the selected sectors. On the other hand, there has been a good practice in terms of identifying clear and valid criteria for performance for which there has been mechanisms to hold the implementing experts accountable. In spite of this, the results show that the company do have a culture of rewarding a good performing individuals and units.

Moreover, the study at hand revealed that there have been changes achieved over the last three years during the implementation of strategic planning. For instance, over the last three years the need for qualified manpower is increased. In addition, the time required to provide services is reduced. Moreover, as a result of strategic planning, National Cement S.C is able to collect more revenue from its business activities within and abroad. However, in some regards, the results show that there are gaps to be filled, particularly in terms of participating a wider employees and stakeholders in the course of designing, implementing and monitoring and evaluating the plan.

\section{Conclusion}

Strategic planning should be preceded by awareness creation communication to those who will be affected by its implementation. This implies that strategic planning is not merely technical, but also encompasses socio-political aspects as well. Hence, its design requires the will and consent of the society in general and the primary stakeholders in particular.

In this regard the study showed that there is gap in terms of getting support from the stakeholders prior to the formulation of the plan.

In addition, as changes may bring both positive and negative impacts, organizations intending to formulate strategic planning need to have open system so as to learn from other organizations operating under similar conditions. This would help the organizations optimize the benefits and minimize the costs to be incurred as a result of implementing the changes.

To this effect, the study revealed that the National Cement S.C had internal and external mechanisms that helped it to benchmark good experience from other organizations based on which the company was able to identify its weaknesses and strengths from the internal environment and its threats and opportunities in the external environment.

Despite the fact that the sectors under consideration have clearly spent out their respective organizational values including vision, mission, goals, values and objectives, all stakeholders were not communicated while 
initiating the formulation of strategic planning. This might have affected the plan not to have participatory attributes which is a key development value in the contemporary world.

Furthermore, proper implementation of strategic planning will help the organizations to be coherent and organized in their operation. This may require more number of qualified manpower which has been noted by this study. The plan also helped the sectors under question to align other reform tools such as BPR, BSC and Change Army.

This paper is one of the few studies to examine the strategic planning process in a sample of firms from a transitional (developing) economy. It can also be considered a longitudinal study because it examines a set of institutions to identify any changes in their performance over time, as they incorporate the use of strategic tools in a dynamic and evolving competitive environment.

Various writers have argued that strategic planning leads to effective company performance. My research question is drawn towards such arguments and also similar past studies. Although similar studies have been carried out elsewhere, this study also doubled up as a replication with extensions study.

This study mainly focused on the contribution of strategic planning process to organizational performance. It would be of interest to investigate the role of intervening variables in translating the strategic planning intentions into reality.

\section{Recommendations}

Any change shall be preceded by understanding and building consensus. This is due to fact that changes bring both positive and negative impacts. Strategic Planning process being one of the tools to bring about changes should begin with creating awareness to the employees and the target stakeholders. Hence, the purposes, processes and perceived success of the plan should be clear for both internal and external environments that may affect the plan or be affected by it in turn. Therefore, in the next revised/updated strategic plan, National Cement S.C should create awareness by short term training when cascading the general plan to the lower level.

In the process of designing Strategic Planning process, participation of the concerned bodies enhances the pace of improving organizational performance. However, it has been found out that there was not adequate participation in the course of designing the plan. Therefore, a researcher recommends that the top-level management at different departments in the company should involve stakeholders and staffs to understand and share the 
organizational values. This is helpful to create a team-spirit and shared accountability.

SMART organizational goals and objectives show where the organization to be in the future. Hence, the planning and monitoring department of the company facilitate to continuously review and evaluate the designed goals and objectives to make them contextual and attainable ones.

Budget is the key aspect in the course of designing, implementing and evaluating Strategic Planning. However, the finding shows that the allocated budget was not adequate to this end. Therefore, it is recommended that the company's Finance department should ensure that the allocated budget is adequate in implementing the earmarked activities of the plan.

In addition, throughout the process of Strategic Planning, the vital resource required is educated manpower along with merit principles which entails putting the right person at the right place. Therefore, the Human Resource Development Department of the company should have mechanisms to ensure that sectors have employed persons with the required qualifications and experiences.

The success of Strategic Planning is dependent on continued monitoring evaluation of organizational performance. Then, the planning and monitoring department facilitate the continuity of monitoring and evaluation in the company's departments.

Designing clear and valid parameters will help to measure the performance progress of the company. Hence, Strategic Planning should involve clear and valid performance indicating criterion that would help to simplify performance evaluation.

Rewarding and celebrating performances motivate employees to work more and more. Hence, this study shows that there is a culture of rewarding and celebrating good performances in the company. Therefore, to motivate poorly performing employees and departments, the good performing employees should be rewarded and appreciated incessantly.

Moreover, the purpose of reforms such as BPR, BSC and Change Army are to improve service delivery. It is argued that these reforms tools must be integrated so as to ultimately enhance customer's satisfaction. Therefore, short-term trainings must be provided so as to widen employees understanding about the principles and practices of these reform tools.

\section{References:}

1. Adegbite, O. (1986). Planning in Nigerian Business. Long Range Planning, 19(4), 98-103. 
2. Akinyele, S.T. (2007). A comparative analysis of strategic marketing management of downstream oil industry in Nigeria. An Extract from Doctoral Dissertation Covenant University Ota-Nigeria.

3. Ansoff, H.I., C.C. Miller \& L.B. Cardinal (2001). Planning and firm performance planning and firm performance a synthesis of more than two decades of research. Acad. Manage. J., 37: 16491665.

4. Ansoff, H.I., Jay A., Richard G. B., Fred E. P. \& Raymond R. (1970): Does Planning Pay? The Effect of Planning on Success of Acquisitions in American Firms, Long Range Planning, December. p. 2-7.

5. Armstrong, J.S. (1999). The value of formal planning for strategic decisions reply. Strategic Manage. J., 7: 183-185.

6. Bateman, T. S., \& Zeithml, C. P. (1993). Management: Function and Strategy. Irwin. Administrative Science Quarterly 12(3), pp. 377-95

7. Burt, D.N. (1998). Planning and performance in Australian retailing. Long Range Plann., 2: 62-66.

8. Caeldries, F. \& Van Dierdonck, R. (1988). How Belgian Business Firms Make Strategic Planning Work. Long Range Planning, 21 (2), April $41-51$.

9. Chandler, A.D.J.R. (1998). Strategy and Structure. Cambridge Mass.

10. Collis, J. \& Hussey, R. (2003). Business Research. 2nd ed. Basingstoke: Pelgrave Macmillan.

11. Cooper, C. \& Schindler, P. (2008). Business Research Methods $\left(10^{\text {th }}\right.$ ed.). Boston: McGraw-Hill.

12. David, F. R. (1997). Strategic Management. New Jersey: Prentice Hall.

13. Davis, W. (2004). Definitions of strategic planning. Woodward Davis Associates.

14. Denning, W. (1997). Corporate Planning Selected Concepts. McGrawHill, London.

15. Drucker, P. (1954). The Practice of Management. Harper Row.

16. Fubara, B. (1986). Corporate Planning in Nigeria. Long Range Planning, 19(2), April, 125-132.

17. Fulmer, R. M. \& Rue, L. W. (1974). The Practice and Profitability of Long Range Planning. Managerial Planning, 22 (6), 1-7.

18. Georgopoulos, B., Tannenbaum, A. (1957), "A Study of Organizational Effectiveness", American Sociological Review 22, pp. 534-40.

19. Gershefski G. W. (1970). Corporate Models - The State of the Art. Management Science, 16(6), 303-312.

20. Grant R. (1998). Contemporary Strategy Analysis: Concepts, Techniques, Applications. Oxford, UK: Blackwell Publishers Inc.

21. Greenley, G. (1986). Does Strategic Planning Improve Company Performance? Long Range Planning, 19(2), April, 101-109. 
22. Griffins, L. W. (2006). Strategic planning: concept and cases. Strategic Management Journal, 16(2), 71-83.

23. Grinyer, P. H. \& Norburn, D. (1975). Planning for Existing Markets. Journal of the Royal Statistical Society, 138(1), 70-97.

24. Gup, B.E. \& D.D. Whitehead (2000). Strategic Planning in banks does it pay. Long Range Plan., 22: 124-130.

25. Haveman, H.A. (1993). Between a rock and a hard place organizational change and performance under conditions of fundamental transformation. Administrative Science Quarterly.

26. Hax, A.C. \& N.S. Majluf (1991). The Strategy Concept and Process a Pragmatic Approach. Prentice-Hall, Englewood Cliffs, New Jersey.

27. Hayes, B. (2003). Benefits of strategic planning. NW Federal Credit Union.

28. Henderson, B. (1979). Henderson on Corporate Strategy. Boston: Abt Books.

29. Herold, D. M. (2001). Long Range Planning and Organizational Performance. Academy of Management Journal, 15, March, 91-102.

30. Hitt, M.A., R.E. Huskisson \& R.D. Ireland (1990). Mergers and acquisitions and managerial commitment to innovation inform firms. Acad. Manage. J., 8: 40-47.

31. Hofer, C. W. \& Schendel, D. (1978). Strategy Formulation: Analytical Concepts. West Publishing Company.

32. Hopkins, W.E. \& S.A. Hopkins (1994). Want to succeed get with the plan. J. Retail Banking, 16: 26-31.

33. Howe, W. S. (1986). Corporate Strategy. London: The Macmillan Press Ltd.

34. Hunger, J.D. (1990). Strategic Management and Business Policy a pragmatic Approach Prentice Hall, Englewood Cliffs, New Jersey.

35. Hunsaker, P.L. (2001). Effects of Formal Strategic Planning on Financial Performance in Small Firms A Meta-Analysis Entrepreneurship Theory and Practice. Dryden Press, Chicago.

36. Imoisili, I. C. (1978). Key Success Factors in Multinational and Indigenous Companies in Nigeria: A Comparative Analysis.Columbia Journal Of World Business, Fall.

37. John M. (2004). Strategic Planning for Public and Non-profit Organizations, $3^{\text {rd }}$ edition, HB Printing, USA.

38. Johnson, G., Scholes, K., \& Whittington, R (2005). Exploring Corporate Strategy: Texts and Cases ( $7^{\text {th }}$ Edition). London: PrenticeHall.

39. Johnson, P. (2002). Business strategy for systematically boosting sales performance using Shortcuts to Yest. Panache and Systems LLC consults. 
40. Kallman, E.A. \& Shapiro (1998). Do long range planning works? Acad. J. Manage., 2: 10-18.

41. Kaplan, R.S., Norton, D.P. (1992), "Putting the Balanced Scorecard to Work", Harvard Business Review, September October, pp. 134-147.

42. Karger, D.W. \& Z.A. Malik (2000). Long range planning and organizational performance. Long Range Plan., 6: 64-64.

43. Kotter, J. P. (1996). Leading Change. Boston Mass: Harvard Business School Press.

44. Kudla, R. J. (1980). The Effects of Strategic Planning on Common Stock Returns. Academy of Management Journal, 23(1), 5-20.

45. Kudla, R. (1996). The effects of strategic planning on common stock returns. Acad. Manage. J., 23: 5-20.

46. Lebans, M., \& Euske, K. (2006), "A conceptual and operational delineation of performance", Business Performance Measurement, Cambridge University Press.

47. Leontiades, M. \& Tezel, A. (2006). Planning Perceptions and Planning Results. Strategic Management Journal, 1 (1), 65-75.

48. Lusthaus, C., \& Adrien, M.-H. (1998), "Organizational assessment: A review of experience", Universalia, 31.

49. Mankins, M. C. \& Steele, R. (2005). Turning Great Strategy into Great Performance. Harvard Business Review, July-August, 65-72.

50. Manoj Kumar (2013). The relation Ship between strategic planning and company performance.

51. McCarthy \& Minichiello (1996). The historical development of the strategic management concept are examination. Acad. J. Manage., 4: 20-27.

52. Miller, C., \& L. Cardinal (1994): Strategic planning and firm performance: A synthesis of more than two decades of research. Academy of Management Journal, 37 (6): 1649-1665.

53. Mintzberg, Henry (1994): "Rethinking Strategic Planning", Part II: New Roles for Planner, Long Range planning, June, p. (23-25).

54. Mugenda, O. M \& Mugenda, A.G. (2008). Research methods, Nairobi: Nairobi Press.

55. Ohmae, K. (1983). The Mind of the Strategist.

56. Paley, N. (2004). Successful business planning. Thorogood Publishers.

57. Patton, M. Q. (2002). Qualitative research. London: John Wiley and Sons Limited.

58. Pealtie, K. (1993). Strategic Planning: Its Role in Organizational Politics. Long Range Planning, 26(3), 10-17.

59. Porter, M. E. (1980). Competitive Strategy: Techniques for Analyzing Industries and Competitors. New York: Free Press. 
60. Porter, M. E. (1985). Competitive advantage: Creating and sustaining superior performance. New York: Free Press.

61. Quinn, J. B. (1980). Strategies for Change: Logical Incrementalism. Homewood IL: Irwin.

62. Ringback, K. A. (1969). Organized Planning in Major U.S. Companies. Long Range Planning, 2(2), December, 46-57.

63. Robinson, D. T. (2003). Strategic alliances and the boundaries of the firm. Review of Financial Studies, 21(2), 649-681.

64. Robinson, R. B. \& Pearce, J. A. (1983). The impact of formalized strategic. American Journal of Small Business, 10(4), 7-16.

65. Robinson, R. B., \& J. A. Pearce II. (1983): The impact of formalized strategic planning on financial performance in small organizations. Strategic Management Journal, 4: 3, 197-207.

66. Wendy R. (1997): "Strategic Management and Information Systems", 1994, p.15.

67. Schwenk, Charles R., \& Charles B. Shrader (1993): Effects of formal strategic planning on financial performance in small firms: A metaanalysis. Entrepreneurship Theory and Practice, 17: 53-64.

68. Shrader, C.B., L.A. Taylor \& D.R. Dalton (1984). Strategic planning and organizational performance critical appraisal. J. Manage., 10: 149171.

69. Steiner, G. A. (1979). Strategic Planning. New York: Free Press.

70. Taylor, B. (1995). The New Strategic Leadership, Driving Change, Getting Results. Long Range Planning, 28(5), 71-81.

71. Thompson, A. A., Strickland, A. J., \& Gamble, J. E. (2007). Crafting and executing strategy: texts and readings. 15th ed., New York: McGraw-Hill.

72. Thune, S.S., \& House, R. J. (1970). Where Long-range Planning Pays Off. Business Horizons, 29, August, 81-87.

73. Tourangeau, K. W. (1987). Strategic Management: How to Plan, Execute, \& Control Strategic Plans for Your Business. New York: McGraw-Hill.

74. Woodburn, T. L. (1984). Corporate Planning in South African Companies. Long Range Planning, 17(1), 84-99.

75. Yavas, U., Kaynak, E. \& Dilber, M. (1985). The Managerial Climate in Less Developed Countries. Management Decision, 23(3), 29-40.

76. Yuchtman, E. \& Seashore, S. (1967), "Factorial Analysis of Organizational Performance", Administrative Science Quarterly 12(3), pp. 377-95.

77. Zikmund, W. G. (2003). Business Research Methods. Mason: Thompson South western. 